\title{
Thermodynamic Studies of the Arsenic Adsorption on Iron Species Generated by Electrocoagulation
}

\author{
J. R. Parga, ${ }^{1}$ V. Vazquez, ${ }^{1}$ and H. Moreno ${ }^{2}$ \\ ${ }^{1}$ Metallurgy and Materials Science Department, Institute Technology of Saltillo, V. Carranza 2400, 25000 Saltillo Coahuila, Mexico \\ ${ }^{2}$ Chemical Engineering Department, Institute Technology of the Laguna, Cuauhtémoc y Revolución S/N, 27000 Torreón, \\ Coahuila, Mexico
}

Correspondence should be addressed to J. R. Parga, drjrparga@hotmail.com

Received 5 June 2009; Accepted 16 August 2009

Recommended by Seetharaman Sridhar

Protection of global environment and sustainable sources of clean water are a necessity for human survival. The wide use of heavy metals by modern industries has generated heavy metals containing wastes and by-products. Specifically, large quantities of arsenic compounds are being discharged into the environment. The full potential of Electrocoagulation (EC) with air injection as an alternative wastewater treatment technique to remove arsenic from water showed more than 99 percent of removal without adding any chemicals. This study has been carried out to determine the feasibility of arsenic adsorption on iron species by EC process using the Langmuir's Isotherm. Thermodynamic parameters such as $\Delta H^{\circ}, \Delta S^{\circ}$, and $\Delta G^{\circ}$ were calculated. It was found that the adsorption process is exothermic and spontaneous. Some experiments were conducted to determine the optimum operating conditions such as current density, $\mathrm{pH}$, and residence time. Also in this study, X-Ray Diffraction, Scanning Electron Microscopy, Mössbauer Spectroscopy, and Fourier Transform infrared spectroscopy were used to characterize the EC solid products that revealed the expected crystalline iron oxides (lepidocrocite, magnetite, gohetite, and iron oxide).

Copyright ( $) 2009$ J. R. Parga et al. This is an open access article distributed under the Creative Commons Attribution License, which permits unrestricted use, distribution, and reproduction in any medium, provided the original work is properly cited.

\section{Introduction}

Arsenic contaminants are generated from various industries such as steel making, electroplating, leather tanning, and industrial operations that involve the processing of ferrous and nonferrous metals. Some other metal wastes associated with these activities include nickel, lead, cadmium, and mercury. Arsenic contaminated natural waters, including surface water and ground water, are a significant problem as some of these compounds are known to be toxic, mutagenic, and carcinogenic. The deleterious health effects associated with ingestion of arsenic require that its concentrations should be kept below $10.0 \mathrm{ppb}$ in potable water supplies. The metals existing in wastewater are usually removed by precipitation. Other treatments used include coagulation, flocculation, ion exchange, solvent extraction, cementation, adsorption, evaporation, filtration and electrochemical, biological, and membrane processes [1]. Seventy percent of electroplating facilities use some form of precipitation treatment [2]. Three types of precipitation treatments in these industries, hydroxide, carbonate, and sulfide precipitation [1], take considerable time and require an extensive setup. Each step takes place in a separate tank, and the entire treatment may require several $\mathrm{pH}$ adjustments as well as the addition of acid coagulant, lime, and caustic or polymeric flocculants. In addition, the process generates large volumes of sludge/waste, which requires disposal. Hydroxide precipitation is the most commonly used precipitation method due to its relative simplicity, low cost, and automatic $\mathrm{pH}$ control [3]. However, most heavy metal hydroxides have similar solubilities; so the most effective $\mathrm{pH}$ must be determined prior to treatment when multiple metals are present at high concentrations (e.g., in metal finishing). Furthermore, it may not be possible to remove all metals simultaneously merely by hydroxide precipitation [4].

Arsenic is conventionally removed by chemical techniques such as treatment with lime, aluminum coagulation, iron coagulation, and chemical oxidation. Other processes used with varying degrees of success include adsorption onto activated carbon, reverse osmosis, nanofiltration, and ion 


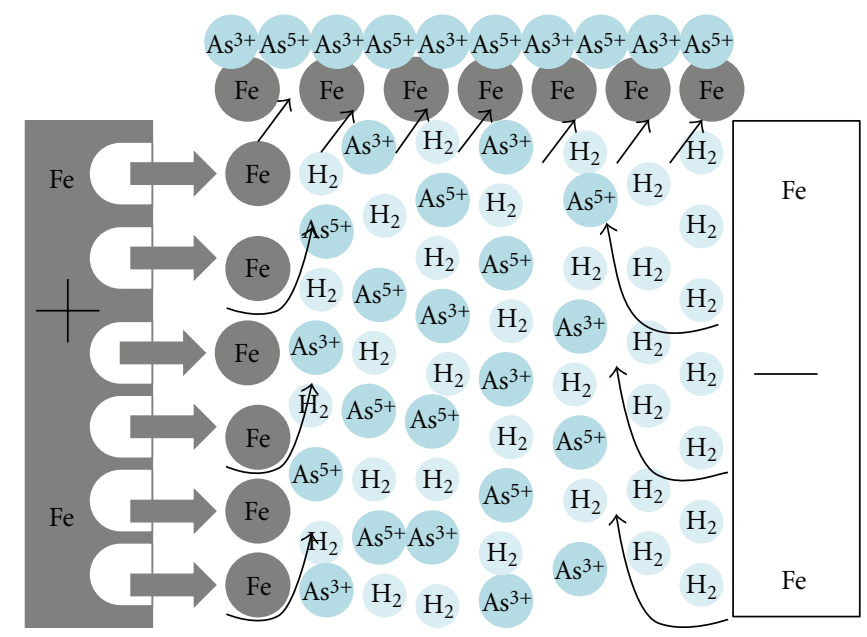

FIGURE 1: An illustration of the EC mechanism (arrows indicate the migration of electrolysis gas $\mathrm{H}_{2}$ ).

exchange resins [5]. These conventional processes generate a considerable quantity of secondary pollutants such as solid sludge, which also pose serious environmental problems.

The Langmuir isotherm was used to obtain the thermodynamic parameters such as free energy, enthalpy, and entropy. Evaluation of these parameters $\left(\Delta G^{\circ}=-34 \mathrm{~kJ} / \mathrm{mol}\right.$, $\Delta H^{\circ}=-29 \mathrm{~kJ} / \mathrm{mol}$ and $\left.\Delta S^{\circ}=-0.0181 \mathrm{~kJ} / \mathrm{mol}^{\circ} \mathrm{K}\right)$ indicates the spontaneous and exothermic nature of the adsorption of arsenic particles on the iron species.

\section{Remediation Technique}

Arsenic removal in the conventional techniques is performed by oxidation of soluble As (Section 3) to less soluble As (Section 4) followed by separation of As (Section 5). Techniques like coagulation-precipitation, adsorption, ion exchange, reverse osmosis, electro dialysis, and so forth take advantage of any of the physicochemical properties. The conversion of As (Section 3) to As (Section 5) is done by using some oxidizing agents like chlorine, potassium permanganate, and so forth. Addition of chemicals in the oxidation step increases the cost of these techniques $[6,7]$. These physicochemical techniques can be classified as shown in Table 1 .

\section{Electrocoagulation Characteristics}

Electrocoagulation has been known as an electrochemical phenomenon since the last century. It has been employed previously for treating many types of wastewater with varying degrees of success. However, most studies have focused on the efficiency of waste removal without exploring the fundamental mechanisms involved in EC [8]. This electrochemical method of waste removal requires smaller quantities of salt addition to increase the conductivity of the solution and the maintenance and operation of the EC cells are relatively simple. Since 1970, this technology has become increasingly popular around the world for treatment of industrial wastewater containing heavy metals [9]. Electrocoagulation processes offer significant potential for removing soluble ionic species from solution, particularly heavy metals [10]. EC operating conditions are highly dependent on the chemistry of the aqueous medium, especially conductivity and $\mathrm{pH}$. Other important characteristics such as particle size, type of electrodes, retention time between plates, plate spacing, and chemical constituent concentrations dictate the operating parameters of the process [11]. The EC process operates on the principle that the cations produced electrolytically from iron and/or aluminum anodes enhance the coagulation of contaminants from an aqueous medium. The sacrificial metal anodes are used to continuously produce polyvalent metal cations in the vicinity of the anode. These cations facilitate coagulation by neutralizing the negatively charged particles that are carried toward the anodes by electrophoretic motion.

A schematic representation of the EC process is shown in Figure 1. As mentioned above, the gas bubbles produced by the electrolysis carry the pollutant to the top of the solution where it is concentrated, collected, and removed. The removal mechanisms in EC may involve oxidation, reduction, decomposition, deposition, coagulation, absorption, adsorption, precipitation, and flotation [14].

EC overall reactions are

$$
\begin{gathered}
\mathrm{Fe}+6 \mathrm{H}_{2} \mathrm{O} \longrightarrow \mathrm{Fe}\left(\mathrm{H}_{2} \mathrm{O}\right)_{4}(\mathrm{OH})_{2(\mathrm{~s})}+\mathrm{H}_{2(\mathrm{~g})} \uparrow \\
\mathrm{Fe}+6 \mathrm{H}_{2} \mathrm{O} \longrightarrow \mathrm{Fe}\left(\mathrm{H}_{2} \mathrm{O}\right)_{3}(\mathrm{OH})_{3(\mathrm{~s})}+1 \frac{1}{2} \mathrm{H}_{2(\mathrm{~g})} \uparrow
\end{gathered}
$$

In the appropriate conditions, iron (II) and iron (III) hydroxides combine in the following proportion to generate Green Rust:

$$
\begin{aligned}
& \mathrm{x} \mathrm{Fe}(\mathrm{OH})_{3(\mathrm{aq})}+(6-\mathrm{X}) \mathrm{Fe}(\mathrm{OH})_{2(\mathrm{aq})} \\
& \longrightarrow \mathrm{x} \mathrm{Fe}(\mathrm{OH})_{3}{ }^{*}(6-\mathrm{X}) \mathrm{Fe}(\mathrm{OH})_{2(\mathrm{~s})}
\end{aligned}
$$

3.1. Green Rust (GR). EC can be considered as an accelerated corrosion process. GR is recognized as an important intermediate phase in corrosion of $\mathrm{Fe}^{0}$ (Figure 2). 
TABLE 1: Comparison of conventional processes for as removal $[12,13]$.

\begin{tabular}{|c|c|c|c|}
\hline Technologies & Advantages & Disadvantages & $\%$ Removal \\
\hline \multicolumn{4}{|l|}{ Oxidation/precipitation } \\
\hline \multirow[t]{3}{*}{ Air oxidation } & $\begin{array}{l}\text { Relatively simple, low-cost but } \\
\text { slow process }\end{array}$ & $\begin{array}{l}\text { Mainly removes arsenic }(\mathrm{V}) \\
\text { and accelerate the oxidation } \\
\text { process }\end{array}$ & \multirow[t]{3}{*}{$80 \%$} \\
\hline & In situ arsenic removal & & \\
\hline & $\begin{array}{c}\text { Also oxidizes other inorganic } \\
\text { and organic constituents in } \\
\text { water }\end{array}$ & & \\
\hline \multirow{3}{*}{ Chemical oxidation } & $\begin{array}{c}\text { Relatively simple and fast } \\
\text { process }\end{array}$ & $\begin{array}{l}\text { Efficient control of the } \mathrm{pH} \text { and } \\
\text { oxidation step is needed }\end{array}$ & \multirow{3}{*}{$90 \%$} \\
\hline & $\begin{array}{l}\text { Oxidizes other impurities and } \\
\text { kills microbes }\end{array}$ & & \\
\hline & Minimum residual mass & & \\
\hline \multicolumn{4}{|c|}{ Coagulation/coprecipitation } \\
\hline \multirow{2}{*}{ Alum coagulation } & $\begin{array}{l}\text { Relatively low capital cost and } \\
\text { simple in operation }\end{array}$ & Produces toxic sludges & \multirow{2}{*}{$90 \%$} \\
\hline & $\begin{array}{c}\text { Durable powder chemicals are } \\
\text { available }\end{array}$ & Low removal of arsenic & \\
\hline \multirow{3}{*}{ Iron coagulation } & $\begin{array}{l}\text { Effective over a wider range of } \\
\mathrm{pH}\end{array}$ & Preoxidation may be required & \multirow{3}{*}{$94.5 \%$} \\
\hline & $\begin{array}{l}\text { Common chemicals are } \\
\text { available }\end{array}$ & Medium removal of As (III) & \\
\hline & $\begin{array}{l}\text { More efficient than alum } \\
\text { coagulation on weigh basis }\end{array}$ & $\begin{array}{l}\text { Sedimentation and filtration } \\
\text { needed }\end{array}$ & \\
\hline Lime softening & $\begin{array}{l}\text { Most common, chemicals are } \\
\text { available commercially }\end{array}$ & $\begin{array}{l}\text { Readjustment of } \mathrm{pH} \text { is } \\
\text { required }\end{array}$ & $91 \%$ \\
\hline \multicolumn{4}{|l|}{ Sorption techniques } \\
\hline Activated alumina & $\begin{array}{l}\text { Relatively well known and } \\
\text { commercially available }\end{array}$ & $\begin{array}{l}\text { Needs replacement after } 4 \text { to } 5 \\
\text { regeneration }\end{array}$ & $88 \%$ \\
\hline & Expected to be cheap & Yet to be standardized & \\
\hline Iron-coated sand & No regeneration is required & Produces toxic solid waste & $93 \%$ \\
\hline & $\begin{array}{l}\text { Remove both As (III) and As } \\
\text { (V) }\end{array}$ & & \multirow{6}{*}{$87 \%$} \\
\hline \multirow{5}{*}{ Ion exchange resin } & $\begin{array}{l}\text { Well-defined medium and } \\
\text { capacity }\end{array}$ & High cost & \\
\hline & $\begin{array}{l}\text { The process is less dependent } \\
\text { on } \mathrm{pH} \text { of water }\end{array}$ & $\begin{array}{l}\text { Requires high tech operation } \\
\text { and maintenance }\end{array}$ & \\
\hline & $\begin{array}{l}\text { Exclusive ion specific resin to } \\
\text { remove arsenic }\end{array}$ & $\begin{array}{l}\text { Regeneration creates a sludge } \\
\text { disposal problem }\end{array}$ & \\
\hline & & As (III) is difficult to remove & \\
\hline & & Life of resins & \\
\hline \multicolumn{4}{|l|}{ Membrane techniques } \\
\hline \multirow{3}{*}{ Nanofiltration } & $\begin{array}{l}\text { Well-defined and high } \\
\text { removal efficiency }\end{array}$ & Very high capital cost & \multirow{3}{*}{$95 \%$} \\
\hline & & Preconditioning & \\
\hline & & High water rejection & \\
\hline Reverse osmosis & $\begin{array}{c}\text { No toxic solid waste is } \\
\text { produced }\end{array}$ & $\begin{array}{l}\text { High tech operation and } \\
\text { maintenance }\end{array}$ & $96 \%$ \\
\hline Electrodialysis & $\begin{array}{l}\text { Capable of removing other } \\
\text { contaminants }\end{array}$ & Toxic wastewater produced & $95 \%$ \\
\hline
\end{tabular}




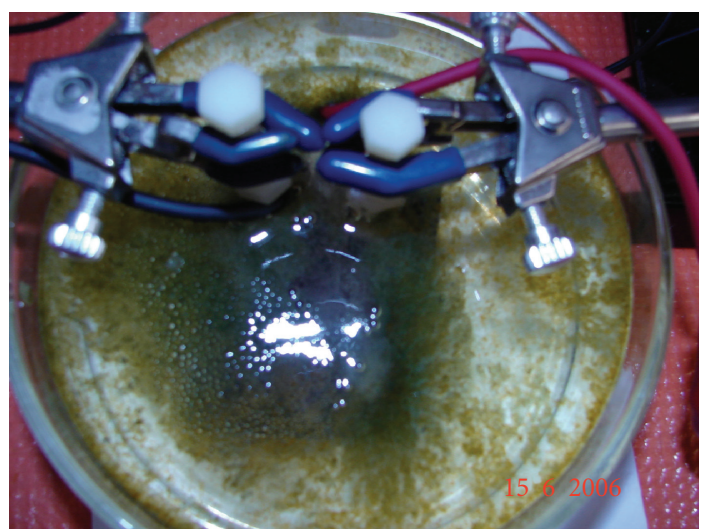

FIGURE 2: Green rust generated with EC.

GRs are layered $\mathrm{Fe}(\mathrm{II})-\mathrm{Fe}(\mathrm{III})$ hydroxides having a pyroaurite-type structure consisting of alternating positively charged hydroxide layers and hydrated anion layers. Some of the $\mathrm{Fe}(\mathrm{II})$ of the octahedral sheets of $\mathrm{Fe}(\mathrm{OH})_{2}$ is replaced by $\mathrm{Fe}$ (III). This results in positive layers of charge that are balanced by the inclusion of anions between the layers [15]. Its exact nature depends on the interlayer anion. Various forms have been synthesized and studied. Results of many studies have shown that GRs conform to a general chemical composition and stoichiometry, that can be represented with the general formula: $\left[\mathrm{Fe}_{(6-\mathrm{x})}^{\mathrm{II}} \mathrm{Fe}_{\mathrm{x}}^{\mathrm{III}}(\mathrm{OH})_{12}\right]^{\mathrm{x}+}\left[(\mathrm{A})_{\mathrm{x} / \mathrm{n} \cdot \mathrm{yH}} \mathrm{O}\right]^{\mathrm{x}-}$, where $\mathrm{x}$ ranges from 0.9 to $4.2, \mathrm{~A}$ is an $\mathrm{n}$-valent anion (typically $\mathrm{CO}_{3}{ }^{2-}, \mathrm{Cl}^{-}$, or $\mathrm{SO}_{4}{ }^{2-}$, and y denotes the varying amounts of interlayer water (typically y ranges from 2 to 4 for most GRs [16].

GRs, unlike most iron oxides in whatever form, have an internal surface area; so these minerals have both large specific surface areas and reactivity. The amphoteric surface hydroxyl groups lead to both sorption of heavy metals (cations) as well as organic anions, for example, linear alkyl benzene sulfonates and inorganic anions, for example, silicate, arsenate, and selenate. Furthermore, polar noncharged compounds are sorbed into the interlayer. Cations as $\mathrm{Cu}(\mathrm{II}), \mathrm{Ni}(\mathrm{II}), \mathrm{Zn}(\mathrm{II}), \mathrm{Cd}(\mathrm{II}), \mathrm{Co}(\mathrm{II})$, and $\mathrm{Mg}(\mathrm{II})$ may isomorphically substitute for Fe(II) during GR formation (co precipitation). For example, nickelous-ferric GR rusts, the end products obtained by substitution of $\mathrm{Fe}$ (II) ions by $\mathrm{Ni}$ (II) ions, have been demonstrated [17-20]. This incorporation of cationic inorganic contaminants into the structures of GR could provide an effective means of sequestering contaminants in the subsurface.

\section{Experimental Details}

For the adsorption tests a beaker size reactor $(400 \mathrm{~mL})$ was used, and it was equipped with two carbon steel electrodes $(6 \mathrm{~cm}$ by $3 \mathrm{~cm}$ ) separated $5 \mathrm{~mm}$. A universal AC/DC adaptor was used as a power source. $\mathrm{pH}$ values were registered with a VWR scientific $8005 \mathrm{pH}$ meter.

To determine the adsorption of arsenic on iron species electrolytic solutions were prepared with sodium arsenate
$\mathrm{Na}_{2} \mathrm{HAsO}_{4}$ (reagent grade with a purity of $97 \%$ made by Monterrey chemical products) and deionized water with a conductivity of $0.95 \mu \mathrm{S}$ (Aldrich Chemical Co. 99.5+\%, A.C.S. reagent, Lot number DI02350AI). Arsenic concentrations in the prepared solutions were $1,2,5,7,13,20$, and $30 \mathrm{mg} / \mathrm{L}$.

Conductivity was adjusted by adding one gram of $\mathrm{NaCl}$ per liter of water (Fisher, $99.8 \%$ A.C.S. Certified, Lot number 995007). Solution and solids were separated by filtration through cellulose filter paper. The sludge from the EC was dried either in an oven or under vacuum at room temperature.

\section{Adsorption Results}

5.1. Calculus of Arsenic Moles Adsorbed on Iron Species. The amount of arsenic at equilibrium $q_{e}(\mathrm{mg} / \mathrm{g})$ on iron species was calculed from the following equation:

$$
N=v^{*}\left(\frac{C_{0}-C_{e}}{W}\right),
$$

where $C_{0}$ and $C_{e}(\mathrm{mg} / \mathrm{L})$ are the liquid phase concentrations of arsenic at initial and equilibrium, respectively, $v$ is the volume of the solution, and $W$ is the mass of adsorbent used (g) (in this case the Fe dissolved from EC) (Table 2).

The metal amount that dissolves or deposits depends on the quantity of electricity that passes across the electrolytic solution and the residence time in the EC cell.

A simple relation between the current density and the quantity of substance dissolved ( $\mathrm{g}$ of $M$ for $\mathrm{cm}^{2}$ ) stems from Faraday's law $[21,22]$ :

$$
W=\frac{\left(D^{*} t^{*} M\right)}{n^{*} F},
$$

where $W$ is the amount of the electrode dissolved $\left(\mathrm{grcm}^{-2}\right)$, $D$ the current density $\left(\mathrm{Acm}^{-2}\right), t$ the time (seconds), $M$ the relative molar mass of the electrode, $n$ the number of electrons in the redox reaction, and $F$ Faraday's constant (96500 coulombs).

The number of arsenic moles adsorbed on iron species is calculated by (4). Results (Table 3) show that arsenic adsorption increases as the arsenic concentration in the solution increases [23].

5.2. Langmuir's Isotherm. The Langmuir equation is given in the following equation:

$$
N=\left(\frac{N_{\max } K_{L} C_{e}}{1+K_{L} C_{e}}\right)
$$

where $N$ is the solid phase adsorbate concentration in equilibrium (mg/g), $N_{\max }$ the maximum adsorption capacity corresponding to complete monolayer coverage on the surface $(\mathrm{mg} / \mathrm{g}), C_{e}$ the concentration of adsorbate at equilibrium $(\mathrm{mg} / \mathrm{L})$, and $K_{L}$ the Langmuir constant (L/mg). Equation (6) can be rearranged to a linear form:

$$
\frac{C_{e}}{N}=\frac{1}{N_{\max } K_{L}}+\frac{C_{e}}{N_{\max }} .
$$


TABLE 2: Conditions for arsenic adsorption tests.

\begin{tabular}{|c|c|c|c|c|c|c|}
\hline Samples & $\begin{array}{c}\text { Initial con- } \\
\text { centration } \\
(\mathrm{mg} / \mathrm{L})\end{array}$ & Initial temperature $\left({ }^{\circ} \mathrm{C}\right)$ & Initial $\mathrm{pH}$ & Intensity current (amperes) & Voltage (volts) & Time $(\min )$ \\
\hline 1 & 1 & 20 & 2.86 & 0.49 & 8.5 & 5 \\
\hline 2 & 2 & 20 & 3.02 & 0.52 & 12 & 5 \\
\hline 3 & 5 & 20 & 2.90 & 0.44 & 10 & 5 \\
\hline 4 & 7 & 20 & 3.05 & 0.41 & 12.8 & 5 \\
\hline 5 & 13 & 20 & 2.90 & 0.48 & 10.7 & 5 \\
\hline 6 & 20 & 20 & 3.02 & 0.5 & 10.25 & 5 \\
\hline 7 & 30 & 20 & 4.17 & 0.75 & 6.68 & 5 \\
\hline
\end{tabular}

It was observed that the equilibrium adsorption data followed Langmuir's model. Langmuir's isotherm (Figure 3) shows the arsenic adsorption capacity on iron species [24, 25]. Constants can be evaluated from the intercepts and the slopes of the linear plots of $C_{e} / N$ versus $C_{e}$.

Table 4 shows the results of linear regression. The value of $N_{\max }$ indicates the maximum adsorption capacity corresponding to complete monolayer coverage on the iron surface. The value of $K_{L}$ is the Langmuir adsorption constant [26].

5.3. Covered Fraction of Arsenic on Iron Species. Equation $\theta=$ $N / N_{\max }$ calculates the covered fraction $(\theta)$ with the obtained results for $N$ and $N_{\max }$. In Table 5 it can observed that the covered fraction $\theta$ approaches 1 when $N$ concentration increases.

\section{Thermodynamic Studies}

The thermodynamic parameters such as change in standard free energy $\left(\Delta G^{\circ}\right)$, enthalpy $\left(\Delta H^{\circ}\right)$, and entropy $\left(\Delta S^{\circ}\right)$ were determined using the following equations:

$$
\begin{aligned}
& \ln \left(\frac{1}{b}\right)=\frac{\Delta G^{\circ}}{R T} \\
& \ln (b)=b_{0}-\left(\frac{\Delta H^{\circ}}{R T}\right), \\
& \Delta G^{\circ} \text { ads }=\Delta H^{\circ} \text { ads }-T \Delta S^{\circ} \text { ads }
\end{aligned}
$$

where $R$ is the gas constant, $\left(\mathrm{Jmol}^{-1}{ }^{\circ} \mathrm{K}^{-1}\right)$ is the absolute temperature, $b$ is Langmuir's constant which is related to the energy of adsorption, and $b_{0}$ is a constant.

Table 6 shows a negative value of $\Delta G^{\circ}$, indicating that arsenic adsorption on iron species by EC is a spontaneous process. The negative value of $\Delta H^{\circ}$ indicates an exothermic process and suggests physisorption according to the value for the liberated heat between -20 and $-40 \mathrm{KJ} / \mathrm{mol}$. The negative value of $\Delta S^{\circ}$ suggests that there is not a significant change in the internal structure of the adsorbent during the adsorption of As $[25,26]$.
TABle 3: Arsenic moles adsorbed on iron species $(N)$.

\begin{tabular}{lcccc}
\hline Sample & $C_{0 \text { As }}(\mathrm{mmol} / \mathrm{L})$ & $C_{e \text { As }}(\mathrm{mmol} / \mathrm{L})$ & $W(\mathrm{grs})$ & $N(\mathrm{mmol} / \mathrm{gr})$ \\
\hline 1 & 0.013347 & 0.0002 & 0.028435 & 0.161827 \\
2 & 0.026695 & 0.0006 & 0.033658 & 0.270655 \\
3 & 0.066737 & 0.0009 & 0.025534 & 0.901994 \\
4 & 0.093432 & 0.0020 & 0.023793 & 1.344981 \\
5 & 0.173518 & 0.0049 & 0.027855 & 2.118223 \\
6 & 0.266951 & 0.0126 & 0.029016 & 3.067147 \\
7 & 0.400427 & 0.0168 & 0.043523 & 3.084857 \\
\hline
\end{tabular}

TABLE 4: Linear regression results for arsenic adsorption.

\begin{tabular}{lc}
\hline$R^{2}$ & 0.9665 \\
\hline$\left.N_{\max }\left(\mathrm{mmol}_{\mathrm{As}}\right) / \mathrm{g}_{\mathrm{Fe}}\right)$ & 4.242681 \\
$K_{L}(\mathrm{~L} / \mathrm{mmol})$ & 181.30 \\
\hline
\end{tabular}

TABle 5: Covered fraction $\theta$ for arsenic.

\begin{tabular}{lcc}
\hline$N(\mathrm{mmol} / \mathrm{gr})$ & $N_{\max }(\mathrm{mmol} / \mathrm{gr})$ & $\theta$ \\
\hline 0.161827 & 4.2426 & 0.038 \\
0.270655 & 4.2426 & 0.064 \\
0.901994 & 4.2426 & 0.213 \\
1.344981 & 4.2426 & 0.317 \\
2.118223 & 4.2426 & 0.499 \\
3.067147 & 4.2426 & 0.722 \\
3.08485 & 4.2426 & 0.727 \\
\hline
\end{tabular}

TABle 6: Thermodynamic Parameters for arsenic adsorption.

\begin{tabular}{lcc}
\hline$\Delta H_{\text {ads }}(\mathrm{kJ} / \mathrm{mol})$ & $\Delta G_{\text {ads }}(\mathrm{KJ} / \mathrm{mol})$ & $\Delta S_{\text {ads }}\left(\mathrm{KJ} / \mathrm{mol}^{\circ} \mathrm{K}\right)$ \\
\hline-34.6885 & -29.3929 & -0.01814 \\
\hline
\end{tabular}

\section{Product Characterization}

It is difficult to differentiate between iron oxide and oxyhydroxide species using only a single analytical technique. In this study, Powder X-ray Diffraction (XRD), Scanning Electron Microscope (SEM), and Transmission Mössbauer Spectroscopy (TMS) were used to characterize the solid products formed from carbon steel electrodes during EC. 
TABLE 7: FT-IR vibrations and their corresponding wavenumbers and region for the bands observed for the EC-by product.

\begin{tabular}{|c|c|c|c|}
\hline Electrode material & Type of vibrations & Vibration wavenumbers $\left(\mathrm{cm}^{-1}\right)$ & Vibration range $\left(\mathrm{cm}^{-1}\right)$ \\
\hline \multirow{10}{*}{ Iron } & \multirow{2}{*}{$\mathrm{OH}$ stretching } & 3738 & $3689-3787$ \\
\hline & & 3447 & $3550-3000$ \\
\hline & Hydroxyl bending & 1637 & $1572-1813$ \\
\hline & $\gamma^{\prime}(\mathrm{OH})$ water bending & 1637 & $1572-1813$ \\
\hline & Overtones of hydroxyl bending & 1637 & $1572-1813$ \\
\hline & Magnetite $\left(\mathrm{Fe}_{3} \mathrm{O}_{4}\right.$ or $\left.\mathrm{Fe}_{3-\mathrm{x}} \mathrm{O}_{4}\right)$ & 575 & $526-840$ \\
\hline & \multirow[t]{2}{*}{$\mathrm{Fe}-\mathrm{O}$} & 469 & $416-510$ \\
\hline & & 1120 & $1090-1245$ \\
\hline & \multirow[t]{2}{*}{ Lepidocrocite } & 1023 & $923-1057$ \\
\hline & & 745 & $730-90$ \\
\hline
\end{tabular}

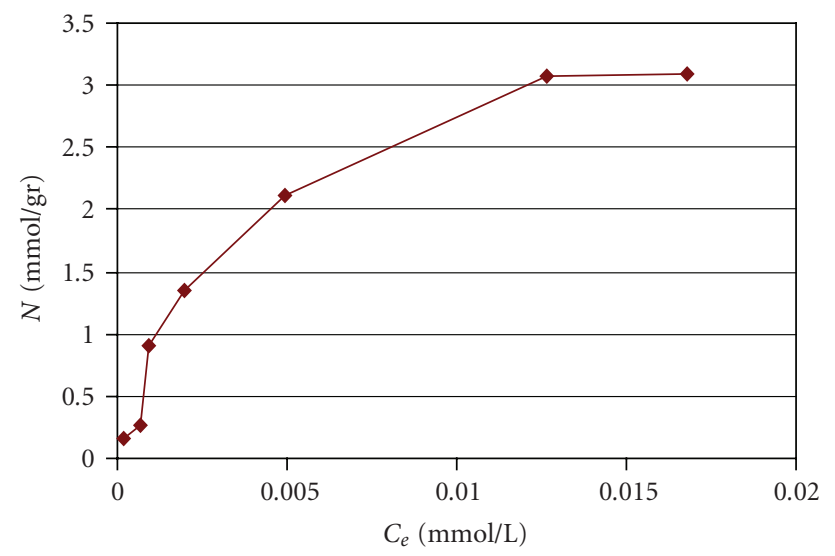

(a)

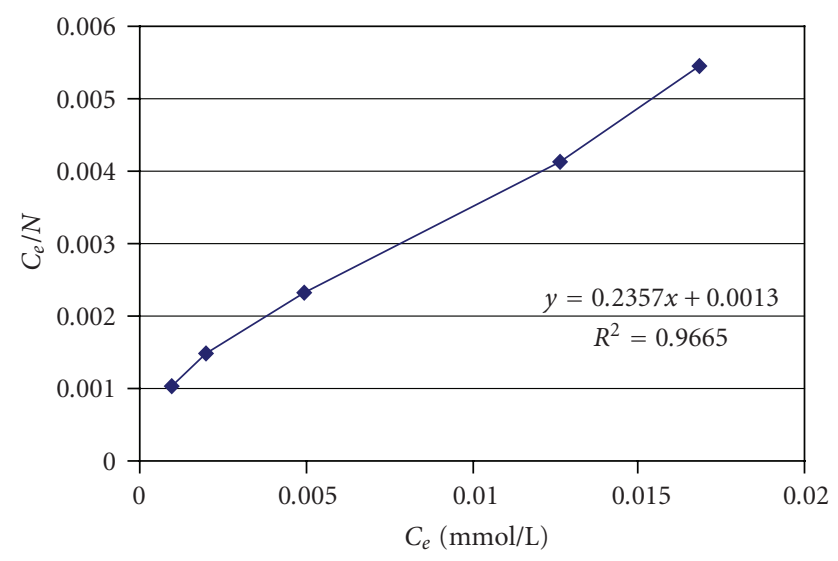

(b)

FIGURE 3: Langmuir isotherm for arsenic adsorption on iron species.

7.1. X-Ray Diffraction. Diffractogram was obtained with a Philips X'Pert MPD system operating with $\mathrm{CuK}_{\alpha}$ radiation source filtered with a graphite monochromator $(\lambda=$ $1.5406 \AA$ ). The spectrum scan rate was set at 0.02 degrees per second. For arsenic a diffractogram was obtained with a Bruker-AXS D4 Endeavor diffractometer operating with

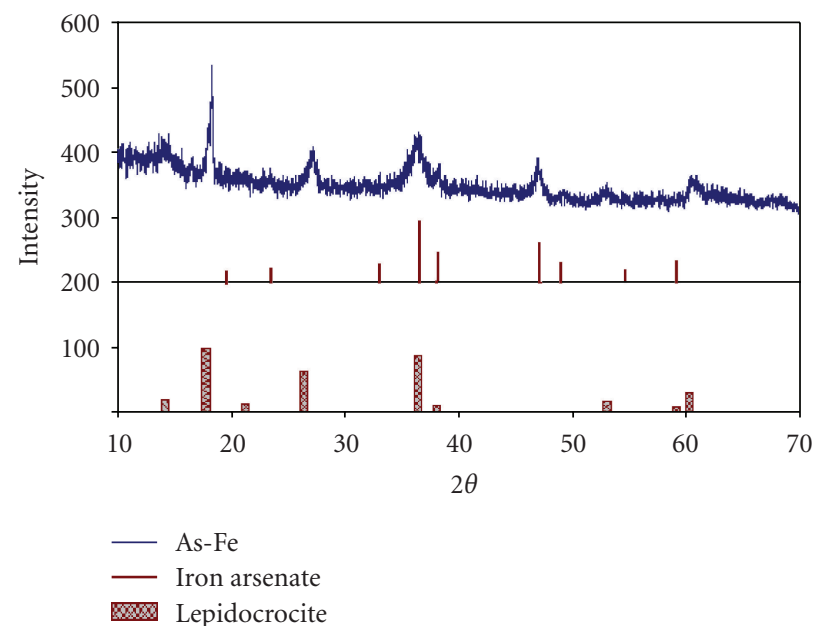

FIGURE 4: XRD of the EC solid products that shows iron impregnated with Arsenic.

$\mathrm{CuK}_{\alpha}$ radiation source filtered with a graphite monochromator $(\lambda=1.5406 \AA)$. The samples were ground to a fine powder in isopropyl alcohol (Sigma-Aldrich) and loaded into a sample holder. The XRD scans were recorded from 20 to 70 degrees $2 \theta$ with $0.020^{\circ}$ step-width, and with 10 seconds counting time for every step-width. Experiments were run at $40 \mathrm{kV}$ and $40 \mathrm{~mA}$. Figure 4 shows the diffractogram of EC solid product sample obtained from a $2 \mathrm{ppm}$ of arsenic solution at $\mathrm{pH}$ 7. The identified species were lepidocrocite and iron arsenate in crystalline form.

7.2. Scanning Electron Microscopy (SEM) and Energy Dispersive Analysis of X-rays (EDAX). Figure 5 shows SEM and EDAX images of As on iron oxide/oxyhydroxide particles, respectively. These SEM and EDAX results show that the surfaces of these iron oxide/oxyhydroxide particles were coated with a layer of As and species.

7.3. Transmission Mössbauer Spectroscopy for Arsenic. Figure 7 shows the spectrum obtained from the EC solid product from $2 \mathrm{ppm}$ arsenic solution $\mathrm{pH}=7.0$. Mössbauer Spectra for each sample was obtained on a $\pm 15 \mathrm{~mm} / \mathrm{s}$ 


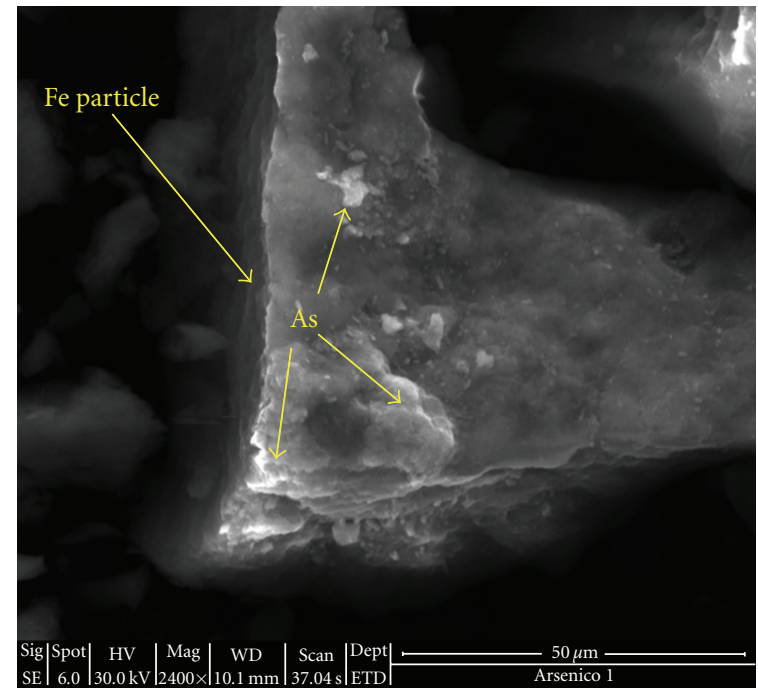

(a)

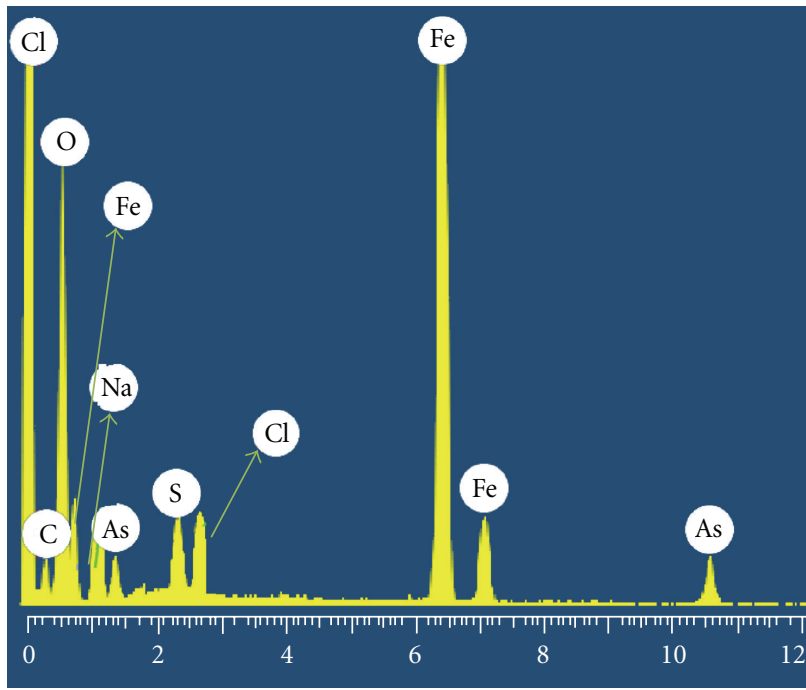

(b)

Figure 5: SEM and EDAX images of by-products generated from the arsenic contaminated water samples.

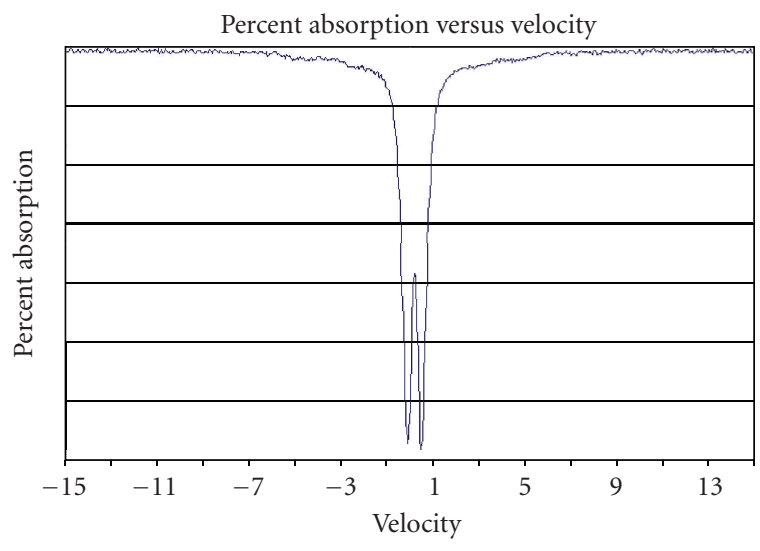

FIGURE 6: Mössbauer spectrum with arsenic at $\mathrm{pH}=7$, indicating the presence of magnetite.

velocity scale, which allows observation of wide magnetic hyperfine spectra expected from iron oxide compounds. The spectrum consists of a doublet magnetic spectrum, which is probably due to fine particles of iron oxides (nonstoichiometric magnetite) or iron hydroxides (Goethite, etc., see Figure 6).

From the analysis of these techniques the in-situ generated small fine particles of iron- oxide/oxyhydroxides in the EC process are nonstoichiometric magnetite, goethite and iron hydroxide oxide. A recent study [18] shows that EC can be combined with magnetic seeding to produce a magnetic aggregate that can be efficiently separated by High-Gradient Magnetic Separation (HGMS) in-line with the EC reactor.

7.4. Fourier Transform Infrared Spectroscopy. FT-IR analyses were carried out by Thermonicolate FTIR spectrometer and OMNIC software using potassium bromide pellets (sample:

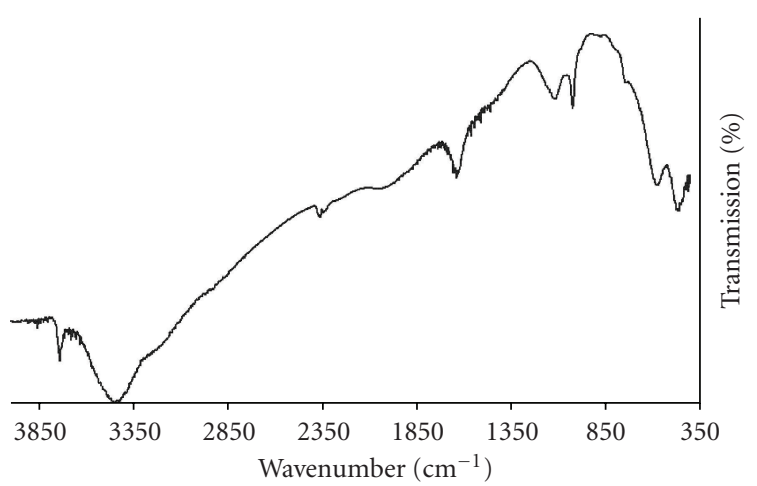

FIGURE 7: FT-IR spectrum of iron electrode by-product.

$\mathrm{KBr}=1: 50$ ). The spectra were usually recorded in the range of $4000-400 \mathrm{~cm}^{-1}$ with $2 \mathrm{~cm}^{-1}$ resolution. 64 scans were collected for each specimen. Figure 7 shows the FT-IR spectrum of the by-product. Infrared analysis of iron electrode by-product showed $\mathrm{OH}$ stretching at 3738 and $3447 \mathrm{~cm}^{-1}$, hydroxyl bending and $\gamma^{\prime}(\mathrm{OH})$ water bending vibration, or overtones of hydroxyl bending around $1637 \mathrm{~cm}^{-1}[19,20]$. Bands for lepidocrocite phase showed up at 1120, 1023, and $745 \mathrm{~cm}^{-1}$ [21]. Magnetite $\left(\mathrm{Fe}_{3} \mathrm{O}_{4}\right.$ or $\left.\mathrm{Fe}_{3-\mathrm{x}} \mathrm{O}_{4}\right)$ band at $575 \mathrm{~cm}^{-1}$ and $\mathrm{Fe}-\mathrm{O}$ vibration band is seen at $469 \mathrm{~cm}^{-1}$ [21, 22]. For details of FT-IR analysis see Table 7. XRD analyses also confirmed the presence of these species detected by FTIR.

\section{Conclusions}

The results of this study indicate that arsenic can be successfully adsorbed on iron species by electrocoagulation process. Based on Langmuir's isotherm analysis, the adsorption capacity was determined to be $4.24 \mathrm{mmol} / \mathrm{gr}$ for arsenic. 
The negative values of $\Delta G^{\circ}$ obtained indicated that the arsenic adsorption on iron species by EC is a spontaneous process. The negative values of $\Delta H^{\circ}$ represent an exothermic process and suggest a physisorption behavior. The negative values of $\Delta S^{\circ}$ suggest that a significant change does not happen in the internal structure of the adsorbent during the adsorption of As. The X-ray diffraction, Scanning Electronic Microscopy, Transmission Mössbauer, and Fourier Transform Infrared Spectroscopy techniques demonstrate that the formed species are of magnetic type, like lepidocrocite which adsorbed the arsenic particles on his surface due to the electrostatic attraction between both metals. The $99 \%$ arsenic removal in the experimental EC reactor is usually completed within 60 seconds (data is not shown here) or less for most experiments with current efficiency of 100\%. EC with the air injection technique built in a robust pilot system is a very promising technology for removal of toxic and heavy metals where adjustment of $\mathrm{pH}$ is not required during the $\mathrm{EC}$ process.

\section{Nomenclature}

$N$ : Number of arsenic moles adsorbed on iron species $\left(\mathrm{mgg}^{-1}\right)$

$C_{0}$ : Initial concentrations of arsenic $\left(\mathrm{mgL}^{-1}\right)$

$C_{e}: \quad$ Equilibrium concentrations of arsenic $\left(\mathrm{mgL}^{-1}\right)$

$W$ : Amount of the electrode dissolved $\left(\mathrm{grcm}^{-2}\right)$

D: Amount of the electrode dissolved $\left(\mathrm{grcm}^{-2}\right)$

$t$ : Time (seconds)

M: Relative molar mass of the electrode

$n$ : Number of electrons in the redox reaction

F: $\quad$ Faraday's constant (96,500 coulombs)

$N_{\max }$ : Maximum adsorption capacity $\left(\mathrm{mgg}^{-1}\right)$

$K_{L}$ : Langmuir adsorption constant

$\theta: \quad$ Covered fraction

$\Delta G^{\circ}:$ Standard free energy $\left(\mathrm{KJmol}^{-1}\right)$

$\Delta H^{\circ}$ : Standard enthalpy $\left(\mathrm{KJ} / \mathrm{mol}^{-1}\right)$

$\Delta S^{\circ}:$ Standar entropy $\left(\mathrm{KJmol}^{-1} \mathrm{~K}^{-1}\right)$

$R$ : Universal gas constant $\left(\mathrm{Jmol}^{-1}{ }^{\circ} \mathrm{K}^{-1}\right)$.

\section{Acknowledgments}

The authors wish to acknowledge support of this project to the National Council of Science and Technology (CONACYT) and to Dirección General de Educación Superior Tecnológica (DGEST).

\section{References}

[1] R. W. Peters, Y. Ku, and D. Bhattacharyya, "Evaluation of recent treatment techniques for removal of heavy metals from industrial wastewaters," in Separation of Heavy Metals and Other Contaminants, vol. 243 of AICHE Symposium Series, pp. 165-203, 1985.

[2] W. Lin, R. C. Viadero Jr., B. E. Reed, and R. L. Vaughan Jr., "Electronics and metal finishing and processing," Water Environment Research, vol. 71, no. 5, pp. 816-822, 1999.

[3] M. Y. A. Mollah, R. Schennach, J. R. Parga, and D. L. Cocke, "Electrocoagulation (EC)—science and applications," Journal of Hazardous Materials, vol. 84, no. 1, pp. 29-41, 2001.
[4] C. Modrogan, L. Bobirica, C. Bobirica, and C. Costache, in Proceedings of the 1st International Conference on Environmental Research and Assessment, Ars Docendi, Bucharest, Romania, 2003.

[5] M. F. Ahmed, "An Overview of Arsenic Removal Technologies in Bangladesh and India," pp. 251-253, 2004, http://www.unu.edu/env/Arsenic/Ahmed.pdf.

[6] P. Mondal, C. B. Majumder, and B. Mohanty, "Laboratory based approaches for arsenic remediation from contaminated water: recent developments," Journal of Hazardous Materials, vol. 137, no. 1, pp. 464-479, 2006.

[7] A. Verma, S. Chakraborty, and J. K. Basu, "Adsorption study of hexavalent chromium using tamarind hull-based adsorbents," Separation and Purification Technology, vol. 50, no. 3, pp. 336341, 2006.

[8] J. Hu, G. Chen, and I. M. C. Lo, "Removal and recovery of $\mathrm{Cr}(\mathrm{VI})$ from wastewater by maghemite nanoparticles," Water Research, vol. 39, no. 18, pp. 4528-4536, 2005.

[9] B. Benguella and H. Benaissa, "Cadmium removal from aqueous solutions by chitin: Kinetic and equilibrium studies," Water Research, vol. 36, no. 10, pp. 2463-2474, 2002.

[10] J. R. Parga, D. L. Cocke, D. E. Mencer, and P. Morkovsky, in Proceedings on Recycling and Waste Treatment in Mineral and Metal Processing: Technical and Economic Aspects, TMS Publishing, Lulea, Sweden, 2002.

[11] V. L. Pogrebnaya, A. A. Klimenko, T. N. Bokovikova, E. P. Tsymbal, and N. P. Pronina, "Purification of waste water of heavy metals by electrocoagulation," Chemical \& Petroleum Engineering, vol. 31, no. 5-6, pp. 280-281, 1995.

[12] A. Seidel, J. J. Waypa, and M. Elimelech, "Role of charge (Donnan) exclusion in removal of arsenic from water by a negatively charged porous nanofiltration membrane," Environmental Engineering Science, vol. 18, no. 2, pp. 105-113, 2001.

[13] N. Balasubramanian and K. Madhavan, "Arsenic removal from industrial effluent through electrocoagulation," Chemical Engineering and Technology, vol. 24, no. 5, pp. 519-521, 2001.

[14] N. P. Barkley, C. Farrell, and T. Williams, "Electro-pure Alternating Current Electrocoagulation," Tech. Rep. EPA/540/S93/504, 1993.

[15] J. R. Parga, D. L. Cocke, V. Valverde, et al., "Characterization of electrocoagulation for removal of chromium and arsenic," Chemical Engineering and Technology, vol. 28, no. 5, pp. 605612, 2005.

[16] J. A. G. Gomes, P. Daida, M. Kesmez, et al., "Arsenic removal by electrocoagulation using combined Al-Fe electrode system and characterization of products," Journal of Hazardous Materials, vol. 139, no. 2, pp. 220-231, 2007.

[17] W. A. Pretorius, W. G. Johannes, and G. G. Lempert, "Electrolytic iron flocculant production with a bipolar electrode in series arrangement," Water SA, vol. 17, no. 2, pp. 133-138, 1991.

[18] N. Mameri, A. R. Yeddou, H. Lounici, D. Belhocine, H. Grib, and B. Bariou, "Defluoridation of septentrional Sahara water of north Africa by electrocoagulation process using bipolar aluminium electrodes," Water Research, vol. 32, no. 5, pp. 1604-1612, 1998.

[19] P. K. Holt, G. W. Barton, and C. A. Mitchell, in Proceedings of the 6th World Congress of Chemical Engineering, Conference Media CD, Melbourne, Australia, 2001.

[20] C. Tsouris, D. W. DePaoli, J. T. Shor, M.-C. Z. Hu, and T.Y. Ying, "Electrocoagulation for magnetic seeding of colloidal 
particles," Colloids and Surfaces A, vol. 177, no. 2-3, pp. 223226, 2001.

[21] S. Goldberg and C. T. Johnston, "Mechanisms of arsenic adsorption on amorphous oxides evaluated using macroscopic measurements, vibrational spectroscopy, and surface complexation modeling," Journal of Colloid and Interface Science, vol. 234, no. 1, pp. 204-216, 2001.

[22] H. D. Ruan, R. L. Frost, J. T. Kloprogge, and L. Duong, "Infrared spectroscopy of goethite dehydroxylation: III. FT-IR microscopy of in situ study of the thermal transformation of goethite to hematite," Spectrochimica Acta, vol. 58, no. 5, pp. 967-981, 2002.

[23] R. Balasubramaniam and A. V. R. Kumar, "Characterization of Delhi iron pillar rust by X-ray diffraction, Fourier transform infrared spectroscopy and Mossbauer spectroscopy," Corrosion Science, vol. 42, no. 12, pp. 2085-2101, 2000.

[24] A. V. R. Kumar and R. Balasubramaniam, "Corrosion product analysis of corrosion resistant ancient indian iron," Corrosion Science, vol. 40, no. 7, pp. 1169-1178, 1998.

[25] S. Goldberg and C. T. Johnston, "Mechanisms of arsenic adsorption on amorphous oxides evaluated using macroscopic measurements, vibrational spectroscopy, and surface complexation modeling," Journal of Colloid and Interface Science, vol. 234, no. 1, pp. 204-216, 2001.

[26] S. Deng and R. Bai, "Removal of trivalent and hexavalent chromium with aminated polyacrylonitrile fibers: performance and mechanisms," Water Research, vol. 38, no. 9, pp. 2424-2431, 2004. 

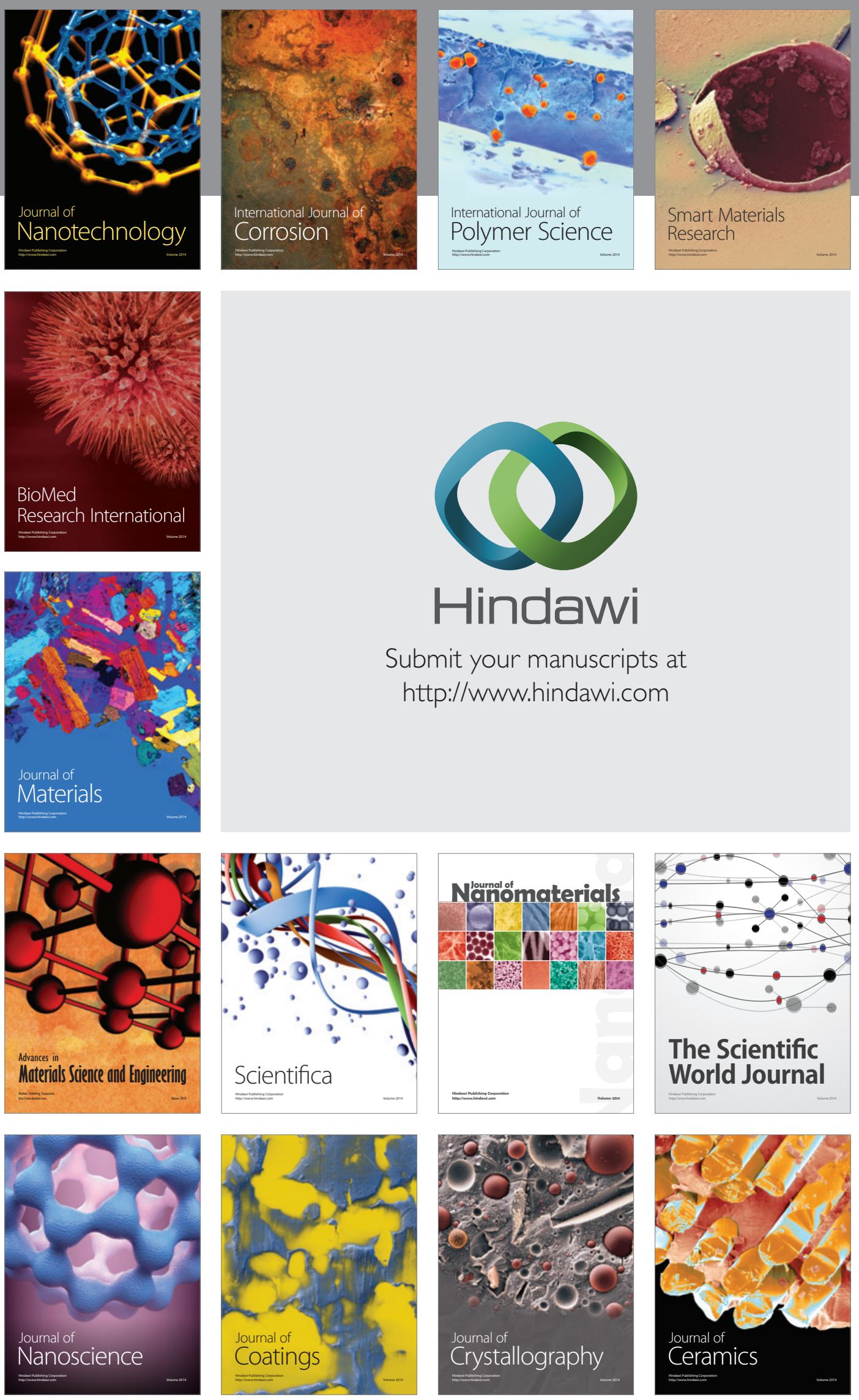

The Scientific World Journal

Submit your manuscripts at

http://www.hindawi.com

\section{World Journal}

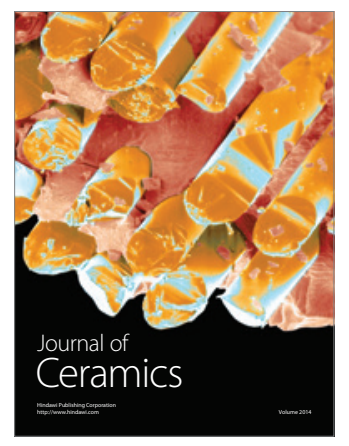

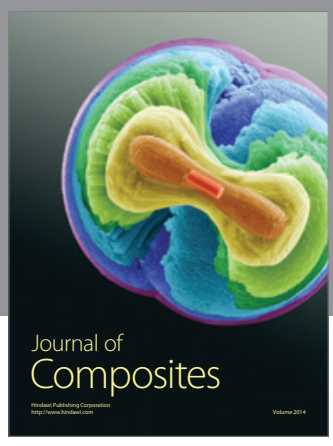
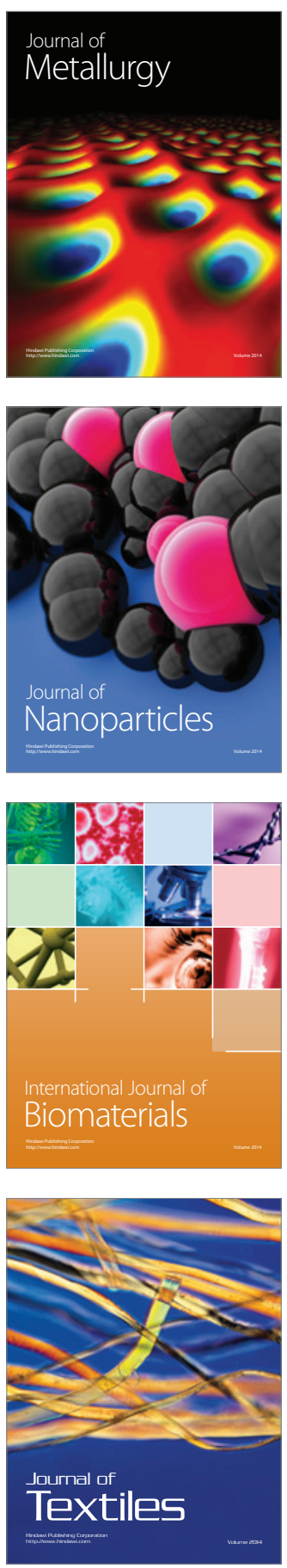